\title{
TEORI HUKUM JA'FARIYAH (ANALISIS HISTORIS MAZHAB FIKIH JA'FAR AS-SHADIQ DAN IMPLIKASINYA PADA PRODUK HUKUMNYA)
}

\author{
Bahrul Hamdi \\ Dewan Masjid Tablighiyah Garegeh, bahrulhamdi@gmail.com \\ Ayen Saputra \\ Pengadilan Agama Lubuk Sikaping, ayensaputra@gmail.com
}

\begin{tabular}{|c|c|c|}
\hline Diterima: 28Juli 2018 & Direvisi : 10 November 2018 & Diterbitkan: 30 Desember 2018 \\
\hline
\end{tabular}

\begin{abstract}
There are two major streams in Islam which up to now have a very significant influence in the Islamic community, namely the Shiite sect and the Ablus Sumnah wa al-Jama'ah sect. Apart from differences in theological discourse, the differences between these two sects also touch the jurisdictions (fiqh). The most obvious differences in fiqh products, for example, appear in the permissibility of marriage if married (contract marriage). Some non-fundamental differences occur in other discourses, such as in prayer, azan, etc. This article intends to discuss legal theory that animates legal products in the Ja'fari school. The presence of Imam Ja'far in his capacity as a respected founder of the Ja'fari school, both Sunni and Shiite, will be discussed specifically in this paper. In addition, this article also discusses a number of figh Ja'fari products which may be fundamentally different from the Sunni fiqh products, including about kbumus and mut'ah. The legal sources used in the Ja'fari school are not much different from the legal sources used in Sunni schools, which revolve around the Qur'an, Sunnah, Ijma', and Intellect. Although there is an understanding of the different definitions of the sourres of the law, this does not indicate that Syi' ah and Sunni have different principles in determining the law.
\end{abstract}

Keyword: Mazhab, figh, Ja'fariyah, Syi'ah

\begin{abstract}
Abstrak
Ada dua aliran besar dalam Islam yang bingga saat ini memiliki pengaruh sangat signifikean dalam masyarakat Islam, yakni aliran Syi'ah dan aliran Ablus Sunnah wa al-Jama'ah. Selain perbedaan dalam wacana teologi, perbedaan antara dua sekte ini juga menyentuh wilayah-wilayah bukum (fikih). Perbedaan dalam produk fikih yang paling nyata misalnya tampak dalam boleh tidaknya penyelengoaraan nikah mut'ah (kawin kontrak). Beberapa perbedaan yang tidak. fundamental terjadi dalam diskursus-diskursus yang lain, seperti dalam shalat, adzan, dan lain sebagainya. Artikel ini bermaksud membicarakan teori bukum yang menjüvai produk-produk bukum dalam maz̧hab Ja'fari. Keberadaan Imam Jaffar dalam kapasitasnya sebagai seorang pendiri mazhab Ja'fari yang disegani, baik di kalangan Sumni maupun Syi'ah akan dikupas secara khusus dalam makalah ini. Selain itu, artikel ini juga mendiskusikan beberapa produk. fikih Ja'fari yang mungkin secara fundamental dianggap berbeda dengan produk. fikih kalangan Sunni, di antaranya tentang kbumus dan mut'ah. Sumber-sumber bukum yang digunakan dalam mazhab Jaffari tidak. jauh berbeda dengan sumber-sumber bukum yang digunakan dalam maz̧bab Sunni, yakni berkisar seputar Alquran, Sunnah, Ijma', dan Akal. Meskipun terdapat pemabaman definisi yang berbeda mengenai sumbersumber bukum tersebut, namun bal tersebut tidak menunjukkan bahwa Syi'ab dan Sunni memiliki perbedaan prinsip dalam penentuan bukum.
\end{abstract}

Kata Kunci: Maz̧ab, Fikih, Ja'fariyah, Syi'ah.

\section{PENDAHULUAN}

Ada dua aliran besar dalam Islam yang hingga saat ini memiliki pengaruh sangat signifikan dalam masyarakat Islam, yakni aliran Syi'ah dan aliran Ahlus Sunnah wa al-Jama'ah. Yang tersebut terakhir ini biasa disebut dengan aliran Sunni. Bibit-bibit munculnya dua sekte besar ini sebenarnya telah muncul sejak wafatnya
Muhammad Rasulullah tahun 634 M, ketika kaum Muslimin bersitegang untuk menentukan siapa yang pantas untuk menggantikan posisi Rasul sebagai pemimpin umat. Namun secara politis, polarisasi antara dua kelompok besar ini muncul pasca pemerintahan Ali ibn Abi Thalib, ketika sekelompok pendukung Ali menentang kehadiran Mu'awiyah sebagai penguasa dunia Islam pasca 
Ali. ${ }^{1}$

Persoalan Syi'ah dan Sunni bermula dari persoalan siapa yang berhak menggantikan posisi Muhammad sebagai pemimpin umat. Kaum Syiah berkeyakinan bahwa kepemimpinan dalam Islam pasca Muhammad adalah hak Ali ibn Abi Thalib dan keturunannya. Sedangkan kelompok Sunni berkeyakinan bahwa persoalan kepemimpinan adalah persoalan keumatan yang harus diputuskan melalui kesepakatan umat. Polarisasi antara dua kelompok ini tampak semakin nyata ketika menyentuh wilayah-wilayah teologis, yang kemudian memunculkan konsep tentang imämah (yang diyakini kelompok Syiah) dan konsep kbiläfah (yang dikemukakan oleh kelompok Sunni). Dua- duanya memiliki landasan teologis ketika melakukan klaim-klaim kebenaran terhadap apa yang diyakininya tersebut.

Selain perbedaan dalam wacana teologi, "sengketa" antara dua sekte ini juga menyentuh wilayah-wilayah hukum (fikih). Perbedaan dalam produk fikih yang paling nyata misalnya tampak dalam boleh tidaknya penyelenggaraan nikah mut'ah (kawin kontrak). Beberapa perbedaan yang tidak fundamental terjadi dalam diskursusdiskursus yang lain, seperti dalam shalat, adzan, dan lain sebagainya.

Eksistensi seorang ilmuwan, teolog, sekaligus fuqahä' bernama Imam Ja'far al-Shadiq menjadi elemen menarik untuk dikaji lebih lanjut. Kecendekiawanan dan keulamaan Imam Ja'far diakui, baik di kalangan Syi'ah maupun Sunni. Di kalangan Syi'ah, Imam Ja'far dianggap sebagai imam keenam dalam teologi Syi'ah, sekaligus sebagai penggagas mazhab Ja'fari, sebuah mazhab fikih yang besar dalam teologi Syi'ah. Di sisi lain, tidak sedikit ahli-ahli fikih dari kalangan Sunni yang sebenarnya merupakan murid dari Imam Ja'far ini, seperti Abu Hanifah dan Malik ibn

${ }^{1}$ M.A. Shaban, Sejarah Islam: (Penafsiran Baru) 600-750, terj. Machnun Husein (Jakarta: Raja Grafindo Persada, 1993), h. 87-112; Badri Yatim, Sejarah Peradaban Islam (Jakarta: Raja Grafindo Persada, 2000), h. 39-40; Fazlur Rahman, Islam, terj. Ahsin Mohammad (Bandung: Pustaka, 1997), h. 249-250.
Anas, yang dalam teologi Sunni, masing-masing merupakan pendiri dua mazhab fikih besar, yakni fikih Hanafiyah dan Malikiyah.

Artikel ini bermaksud membicarakan teori hukum yang menjiwai produk-produk hukum dalam mazhab Ja'fari. Keberadaan Imam Ja'far dalam kapasitasnya sebagai seorang pendiri mazhab Ja'fari yang disegani, baik di kalangan Sunni maupun Syi'ah akan dikupas secara khusus dalam makalah ini. Selain itu, artikel ini juga mendiskusikan beberapa produk fikih Ja'fari yang mungkin secara fundamental dianggap berbeda dengan produk fikih kalangan Sunni, di antaranya tentang khumus dan mut'ah.

\section{BIOGRAFI JA'FAR ASH-SHADIQ}

Nama lengkapnya adalah Abu 'Abdullah Ja'far ibn Muḥammad al-Baqir ibn 'Ali Zaynal Abidīn ibn Husayn ibn Ali ibn 'Abi Ṭalib al-Hashimi al'Alawi al- Madani al-Șadiq. ${ }^{2}$ Ia dilahirkan pada tahun $80 \mathrm{H} / 699 \mathrm{M}^{3}$ Para sejarawan berbeda pendapat mengenai kelahiran Ja'far ini. Selain tahun $80 \mathrm{H}$., ada pula yang mengatakan bahwa ia dilahirkan pada tahun $83 \mathrm{H}$. Ada pula yang mengatakan Ja'far dilahirkan sebelum kedua tahun tersebut. Namun riwayat yang paling kuat menyatakan bahwa Ja'far Shadiq dilahirkan pada tahun $80 \mathrm{H}$, yakni di tahun yang sama dengan kelahiran pamannya, Zayd ibn 'Ali Zaynal 'Abidin. ${ }^{4}$

Ayahnya, Muhammad al-Baqir (w. $115 \mathrm{H}$ ), adalah seorang ulama terkemuka di Madinah yang menjadi rujukan banyak ahli fikih saat itu. Di

\footnotetext{
2 Shihāb al-Dīn Abū al-Faḍl Aḥmad ibn 'Alī ibn Ḥajar al-'Asqalanī, Tahdhïb al-Tahdhib, jilid I (t.tp. : Dār al-Kitāb alIslāmī, t.th.), h. 103.

${ }^{3}$ Cyril Glasse, Ensiklopedi Islam (Ringkas), terj. Ghufron A. Mas'adi, ed. 1 (Jakarta: Raja Grafindo Persada, 1999), h. 189

${ }^{4}$ Lihat Muhammad Abū Zahrah, Tärikh al-Madhäbib alIsläminyah, jilid II (Beirut: Dār al-Fikr al- 'Arabī, t.th.), h. 505; alImām Abū Hātim Muḥammad ibn Aḥmad ibn Hibbān alBust̄i, Mashabir Ulamäi al-Amșār, (ed.) Majdīi ibn Manșūr b. Sayyid al-Shūrā, (Beirut: Dār al-Kutb al-Tlmiyyah, 1416/1995) h. 156; al-Imām Abū Muhammad 'Alī ibn Aḥmad ibn Sa'̄d b. Hazm al-Andalūsī, Asḥāb al- Futyā min al-Sahhäbah wa al-Täbì̄n wa Man Ba'dahum 'alā Marätibihim fì Kathrati al-Futyā (Beirut: Dār al-Kutb al-Ilmiyyah, 1415/1995), h. 149.
} 
antara murid-muridnya antara lain Sufyan alThawri (w. 161 H.) dan Abu Hanifah (w. 150 H.). Ibunya, Ummu Farwah, juga tergolong wanita terhormat di masanya. Ummu Farwah adalah puteri Qasim ibn Muhammad ibn Abu Bakr alȘiddiq. Ibu dari Ummu Farwah sendiri adalah Asma' ibn 'Abdurraḥman ibn Abu Bakr al-Șiddiq, sehingga kadang-kadang Ja'far berkata bahwa dirinya "dilahirkan dua kali oleh Abu Bakr"." Dengan demikian, dari pihak ayah, Ja'far memiliki garis keturunan dengan Rasulullah SAW, sedangkan dari pihak ibunya, ia memiliki garis keturunan dengan Abu Bakr al-Ṣiddiq. Itulah sebabnya mengapa, meskipun ia merupakan salah satu dari Imam kaum Syi'ah, ia akan marah besar bila mendengar ada orang yang merendahkan kakeknya, Abu Bakr al- Șiddiq. ${ }^{6}$ Di lingkungan keluarga terhormat tersebut, Ja'far lahir dan dibesarkan. Ali Zaynal 'Abidin, kakeknya yang merupakan ahli fikih dan tokoh terkemuka di Hijaz ketika itu, juga turut merawat dan mendidiknya sebelum sang kakek tersebut wafat ketika Ja'far berusia 14 tahun. Selain itu, kakek dari pihak ibu, Qasim ibn Muhammad juga menjadi guru dan pembimbingnya. ${ }^{7}$ Begitu pula halnya dengan para tabi'in, yang saat itu masih banyak yang hidup, juga tidak sedikit yang menularkan ilmunya kepada putera Muhammad al-Baqir ini.

Selain dikenal sebagai ahli fikih, Imam Ja'far juga dikenal menguasai ilmu filsafat, tasawuf, kimia, dan kedokteran. Di antara muridnya dalam ilmu alam adalah Jabir ibn Hayyan, seorang ahli kimia dan kedokteran abad ke-8. Selain itu, Imam Ja'far juga dianggap sebagai guru besar dalam dunia sufi, baik sufi dikalangan Syiah maupun Sunni. Ja'far termasuk dalam silsilah utama di dunia tariqah. ${ }^{8}$ Lantaran kepakarannya di bidang h. 103 .

${ }^{5}$ Ibn Ḥajar al-'Asqalānī, Tahdhīb al-Tabdhīb, jild I,

${ }^{6}$ Ibn Hazm al-Andalūsī, Ashǟb al-Futyāà, h. 149.

7 al-Qāsim ibn Muhạmmad ibn Abū Bakr al-Ṣiddīq saat itu juga dikenal sebagai ulama dan ahli fikih yang tergolong dalam fuqabä al-sab'ab di Madinah. Ia wafat pada tahun 108 ketika Ja'far berusia 28 tahun. Ibid., h. 505-507.

${ }^{8}$ Cyril Glasse, Ensiklopedi Islam, h. 189-190; Lihat pula Muhammad Jawwād Mughniyyah, Fïh Imām Jảfar Șädiq, terj. fikih, kaum Syi'ah Ithna Asy'ariyyah menganggapnya sebagai pendiri "mazhab hukum” kelompok ini. Mazhab hukum Syi'ah Ithna Asy'ariyyah sendiri sering disebut dengan maşab Ja'fari. Kepakaran Imam Ja'far di bidang hukum tidak hanya diakui di kalangan Syi'ah saja, namun juga di dunia Sunni. Ia banyak memiliki murid-murid dari kalangan Sunni. Dua orang imam besar dalam fikih Sunni adalah muridnya, yakni Abu Hanifah al-Nu'man (w. $150 \mathrm{H}$ ) dan Malik ibn Anas (w. 179 H). Hadis-hadis yang diriwayatkan olehnya pun diterima di kalangan Sunni. Bahkan para kritikus hadis di kalangan Sunni mengkategorikannya dalam derajat thiqah. ${ }^{9}$

Ja'far merupakan tokoh yang sangat penting dalam sejarah perkembangan Syi'ah. Sebelumnya, Syi'ah cenderung bersifat politis yang memposisikan dirinya sebagai gerakan oposisi terhadap pemerintahan Umayyah. Ja'far mengubah orientasi gerakan Syi'ah ini menjadi bercorak keagamaan. ${ }^{10}$ Ja'far secara pribadi dikenal sebagai orang yang tak menyukai keterlibatan langsung dalam dunia politik. Pengalaman pahit yang dimiliki leluhurnya di medan politik mungkin mempengaruhi sikapnya ini. Terbunuhnya Ali ibn Abi Thalib, Hasan dan Husein putera Ali, dan beberapa kerabat lain yang tewas karena persoalan politik tampaknya mempengaruhi keputusannya untuk menjauhi politik. Karena itu tidak aneh jika Ja'far lebih menyukai bergelut di dunia pengetahuan dari pada terjun langsung di arena politik. ${ }^{11}$

Kendati demikian, bukan berarti Ja'far al-Sâdiq termasuk pribadi yang politis. Imam keenam dalam teologi Syiah ini tetap memiliki perhatian terhadap persoalan-persoalan politik. Ia berani mengkritik pemerintahan Bani Abbasiyah yang dianggapnya zalim dan sewenang-wenang. ${ }^{12}$

Samsuri Rifa'i, dkk. (Jakarta: Lentera Basritama, 1999), h. cover belakang, Ibn Hajar al-'Asqalānī, Tahdhìb al-Tahdhïb, jilid I, h. 103; Aḥmad Amīn, Fajr al-Islàm (t.tp: Dār al-Kutb, 1975), h. 165. 103-104.

9 Ibn Hajar al-'Asqalānī, Tabdhïb al-Tabdhïb, jilid I, h.

${ }^{10}$ Cyril Glasse, Ensiklopedi Islam, h. 189-190.

${ }^{11}$ Muhammad Abū Zahrah, Tärikeb Madhähib, h.519.

12 Badri Yatim, Sejarah Peradaban Islam, h. 49-50. 
Secara tegas ia menolak penggunaan "namanya" untuk kendaraan politik, seperti terlihat misalnya dalam gerakan oposisi di Iraq. Gerakan oposisi yang dipimpin oleh Abu al-Khițab Muhammad ibn Abi Zaynab al-Ajda' tersebut mengobarkan semangat pendukung Ali dengan menggunakan sentimen Ablu al-Bayt. Dalam kampanyenya, Abu al-Khitab menyatakan bahwa Ali ibn Abi Thalib adalah juga seorang rasul seperti halnya Muhammad. Bedanya adalah, Muhammad adalah rasul yang "berbicara", sedangkan Ali adalah rasul yang "diam". Ia juga menyatakan bahwa anak cucu Husein adalah "putera-putera" Allah dan kekasih- Nya di dunia yang harus ditaati. Ia menambahkan bahwa para kekasih Tuhan tersebut juga mewajibkan manusia untuk menaati dirinya sebagai pemimpin. Gerakan Abū al-Khițāb ini ditolak tegas oleh Ja'far al-Șādiq dengan menyatakan bahwa siapapun yang menyatakan hal tersebut adalah musyrik. ${ }^{13}$

Imam Ja'far memang pernah datang ke Kufah, Iraq dan menetap di sana selama beberapa waktu (sekitar 132 H/750 M). Hanya saja kedatangannya ke Iraq itu tidak untuk maksud melakukan agitasi terhadap para pengikutnya, yang memang banyak terdapat di Kufah, untuk melawan pemerintahan saat itu. Kedatangannya ke Kufah ini untuk meneguhkan eksistensi imämah yang diyakini di kalangan Syi'ah. Di sini Imam Ja'far menemukan ekspresi doktrinalnya. Saat itulah ajarannya direkam dan dicatat oleh para muridnya secara sistematis. ${ }^{14}$

Seperti kakek moyangnya, Abu Bakar al-Ṣidiq, Ja'far mendapatkan gelar "al- Șadiq" karena kejujuran sifatnya. Selain itu, ia juga terkenal dengan keikhlasan, kesabaran, kedermawanan, dan keberaniannya. ${ }^{15} \mathrm{Ja}^{\prime}$ far al-Ṣādiq wafat pada tahun $148 \mathrm{H} / 765 \mathrm{M}$ pada usia 68 tahun dan

13 Abū Zahrah, Tärikh al-Madhähib., h. 520-522.

14 Abdul Azis Dahal (ed.), Ensiklopedi Hukum Islam, jilid 3 Jakarta: Ichtiar Baru van Hoeve, 1996) h. 795; Muhammad Abū Zahrah, Tärìkh al-adhähib, h. 517-519.

15 Thomas Patrick Hughes, Dictionary of Islam (New Delhi: Cosmo Publications, 1982), h. 224. Lihat pula Muḥammad Abū Zahrah, Tärikeh al-Madhābib, h. 505, 526-532. dimakamkan di Baqi', di dekat makam ayah dan kakeknya, serta makam Hasan ibn Ali ibn Abi Thalib. ${ }^{16}$

\section{PERKEMBANGAN MAZHAB JA'FARI}

Menurut Mahmud Syihabi, seperti dirujuk oleh Dahal, perkembangan mazhab Ja'fari dibagi atas dua periode utama.

Periode pertama adalah periode penetapan hukum, yang dimulai dari diutusnya Muhammad sebagai rasul sampai wafatnya beliau pada tahun $11 \mathrm{H} / 632 \mathrm{M}$. Periode kedua adalah periode interpretasi hukum, yakni dari tahun $11 \mathrm{H} / 632 \mathrm{M}$ sampai sekarang.

Periode interpretasi tersebut dapat dibagi menjadi empat tahap utama. Tahap pertama, yakni era para sahabat Nabi (11-93 H/632-711 M). Tahap kedua terjadi pada era pengganti Nabi hingga masa "keghaiban kecil" Imam Mahdi (260 H/873 M). Periode kedua ini dapat lagi dibagi menjadi dua fase, yaitu masa Imam Muhammad al-Bāqir serta Imam Ja’far al-Șādiq, dan fase pasca Imam Ja'far al- Șādiq. Tahap ketiga, yakni era para wakil khusus, yaitu pada tahun 260-329 H/873-940 M. Tahap keempat yakni era keghaiban besar, yakni pada tahun 329 H/940 M sampai sekarang.

Menurut Dahal, kajian tentang perkembangan mazhab Ja'fari yang agak terfokus dan komprehensif dilakukan oleh Ahmad Kazemi Moussavi, seorang ahli fikih Iran. Kazemi memulai perkembangan Mazhab Ja'fari sejak masa di mana mazhab Ja'fari menemukan ekspresi doktrinalnya di sekitar tahun 132 H/750 M, yakni ketika Imam Ja'far melakukan perjalanan ke Kufah. Seperti diketahui, pada masa inilah ajaran-ajaran Ja'far al-Șādiq dicatat dan direkam oleh para muridnya secara sistematis. Periode pertama ini berlangsung sampai tahun 408 H/1017 M ketika muncul kaum usuli yang banyak melakukan penalaran dalam hukum. Masa awal ini

16 Muhammad Abū Zahrah, Tārïkh al-Madhähib, h. 508509; Ibn Hibbān al-Bustī, Mashabir 'Ulamä'

al-Amșār, h. 156. 
ditandai dengan munculnya usaha mengumpulkan hadis yang diriwayatkan oleh para imam Syi'ah. Usaha yang terpusat di kota Ray dan Qum ini menghasilkan 400 hadis riwayat para imam yang dikenal dengan al-Ușūl al-Arba' Mi'ah (empat ratus sumber hukum). Usaha ini kemudian diteruskan oleh Abū Ja'far Muḥammad ibn Ya'qub alKilyānī (w. 329 H/940 M) dan Muḥammad ibn 'Alī ibn Babuwayh al-Sadūk (w. 381 H/991 M). Al-Kilyānī mengumpulkan hadis-hadis dalam karyanya al-Käfi. Sedangkan al-Sadūk mengumpulkan hadis-hadis dalam karyanya Man Là Yahdurubu al-Faqīh.

Mazhab Ja'fari memasuki fase baru ketika Muḥammad ibn Muḥammad ibn Nu'mān yang terkenal dengan nama Shaykh Mufid (336-413 H) menerapkan argumen Ușütì rasional dalam menulis karyanya al-Muqni'ah fì al-Ușül wa \%- Furü'. Dengan munculnya pemikiran uṣüt yang diterapkan Shaykh Mufid ini, Mazhab Ja'fari pecah menjadi dua aliran, yakni aliran Akbbarin, yakni aliran para ahli hadis yang tidak mau menggunakan rasio, dan aliran Ușülì yang melakukan upaya penggalian hukum dengan menggunakan rasio. Usaha Shaykh Mufid ini diteruskan oleh ulama-ulama setelahnya, antara lain Sayyid al-Murtạ̣ā (355- 436 H) dan al-Ṭūsī. Usaha Sayyid al-Murtạ̣ā ini konon tidak terlepas dari dukungan pemerintah yang berkuasa saat itu, yakni Dinasti Buwaih, yang mengangkatnya menjadi quậ̀ di Baghdad. Aliran Ușūth dalam mazhab Ja'fari semakin mendominasi wacana hukum melalui peran ulama-ulama berikutnya, antara lain Najm al-Dīn Ja'far ibn Ḥasan alMuḥaqqiq al-Hilli (w. 676/1277M) dan al-'Allāmah ibn Muțahhar al-Hillī. Ulama yang disebut terakhir ini mencoba menyoroti aspek rasional fikih Syiah serta perbandingannya dengan fikih Sunni, yang kemudian berakhir pada interaksi teoritis SunniSyiah.

Aliran Akbbāri kembali bangkit pada abad ke-10 H/16 M. Kebangkitan kembali aliran ini berawal dari reaksi atas interaksi Sunni-Ușülèyang dibuat alHilli. Namun demikian, kebangkitan aliran ini tidak terlepas dari berkuasanya dinasti Safawī (907 H/1501 M) yang menjadikan ideologi Syiah secara menyeluruh sebagai basis kekuasaannya. Sementara dinasti ini dikenal lebih cenderung kepada hadis dan fatwa imam. Ulama akbbārì masa ini di antaranya adalah Ibn Abī Jumhur (akhir abad ke-9 H), Muḥammad Taqī al-Majlisī (w. 1070 H/1660 M), dan Muḥammad Amīn al-Astarabadī (w. 1036 $\mathrm{H})$.

Meskipun aliran Akbbārì mendominasi masa dinasti Safawi, namun aliran Usǚth masih tetap bertahan melalui tulisan-tulisan Hasan ibn Zayn al-Dīn al- 'Āmilī (w. 1011 H/1602 M), Aḥmad ibn Muhammad al-Ardabilī (w. 993 H/1585 M), Bahauddīn al-'Ámilī (w. 1030 H/1631 M), dan lain-lain. Aliran Ușū̄i ini kembali mendapatkan angin segar pas ca jatuhnya dinasti Safawi pada tahun $1153 \mathrm{H} / 1740 \mathrm{M}$.

\section{SUMBER HUKUM MAZHAB JA'FARI}

Pada dasarnya, tidak ada perbedaan mendasar dalam metodologi hukum Syi'ah dan Sunni. Sebagaimana mazhab-mazhab fikih Sunni, mazhab Ja'fari menempatkan Alquran sebagai sumber utama, kemudian diikuti oleh Sun- nah, ijma', dan akal. Menurut mazhab Ja'fari, dalam menggali hukum dari al- Qur'an, seseorang tidak selalu harus berpegang kepada makna lahirnya, tetapi lebih utama sekali adalah makna batinnya. Untuk mendapatkan makna batin tersebut, seorang pengikut mazhab Ja'fari harus mempunyai marja', atau tempat meminta, yakni para imam. ${ }^{17}$

Atas dasar ini, kaum Ja'fariyah menganggap para imam sebagai al-Qur'ān al-nätiq, yakni Alquran yang bisa berbicara, sementara yang berupa muṣhaf disebut dengan al-Qur'ān al-șamit atau Alquran yang diam. Kandungan yang terdapat dalam al-Qur'àn al-șämit bersifat mujmal (global), karena itu seorang penganut mazhab Ja'fari harus berpegang pada pemahaman para imam. Pemahaman para imam tidak akan bertentangan dengan spirit Alquran, sebab mereka merupakan orang-orang yang telah mendapat petunjuk dari Allah dan terlepas dari dosa (ma'șum). ${ }^{18}$

17 Alhaji A.D. Ajilola, Introduction to Islamic Law, h. 45; Abdul Aziz Dahal (ed.), Ensiklopedi Hukum Islam, jilid 3, h. 797.

18 Abdul Aziz Dahlan, Ensiklopedi Hukum Islam, h. 
Pedoman kedua setelah Alquran dalam mazhab Ja'fari adalah Sunnah. Sunnah menurut mazhab ini adalah ucapan, tindakan, dan pembenaran melalui diamnya Nabi dan para imam yang ma'șüm. ${ }^{19}$ Pemahaman semacam ini menunjukkan perbedaan dengan kalangan Sunni yang hanya menisbahkan term Sunnah tersebut hanya kepada Nabi Muhammad. ${ }^{20}$ Mazhab Ja'fari meng anggap ucapan, tindakan, dan pembenaran melalui diamnya para imam juga sebagai Sunnah. Oleh karena itu, segala sesuatu yang berasal dari para imam ma'șùm sama implikasinya secara hukum dengan yang berasal dari Nabi Muhammad.

Posisi imam yang seperti itu merupakan konsekuensi teologis dari kepercayaan bahwa para imam ma'șum adalah pewaris Nabi dalam menyampai- kan risalah Tuhan. Mereka tidak pernah melakukan kesalahan dalam menyampaikan risalah Tuhan, sebagaimana Nabi pun tak pernah melakukan ke- salahan dalam menyampaikan risalah-Nya. Pengertian Sunnah yang di- kemukakan mazhab Syi'ah ini memiliki landasan teologis yang mereka yakini, baik dalam Alquran maupun hadis Nabi.

Seperti halnya mazhab-mazhab hukum dalam Sunni, menurut mazhab Ja'fari tidak semua hadis dapat dijadikan landasan hukum. Hadis yang dapat diterima hanyalah hadis șahīh. Kendati demikian, dalam mazhab Syi'ah terdapat pula aliran Akbbäri yang tidak mau membedakan antara hadis da'if dan hadis șahīh. Kelompok Akbbärì ini menolak rasionalitas dalam hukum. Menurut mereka, semua hadis dapat diterima sebagai dasar hukum tanpa harus melalui test kesahihan. Karena itu menurutnya, seluruh hadis yang terdapat dalam empat kitab hadis mu'tabar di kalangan Syi'ah harus diterima secara keseluruhan. Keempat kitab hadis tersebut adalah: 1) al-Käfì karya al-Kilyānī, 2) Man Là Yahzurubu al-Fāqib karya al-Sadūk, 3) al-Tahdhìb

797.

19 Ibid., h. 797; Lihat pula Murtadha Muthahhari dan Ayatullah Baqir ash-Shadr, Pengantar Ushul Figh dan Ushul Fiqh Perbandingan, terj. Satrio Pinandito dan Ahsin Muhammad (Jakarta: Pustaka Hidayah, 1993) h. 144.

20 'Abd al-Wahhāb Khallāf, Ilm al-Uṣūl Fiqh, (Beirut: Dār al-Qalam, 1978/1398) h. 36. dan 4) al-Istibșār. Dua buah karya terakhir ini dikarang oleh Muhạmmad ibn Ḥasan ibn 'A đ̄i Abū Ja'far al-Ṭūsī (w. 460 H/1067 M). ${ }^{21}$

Sumber hukum ketiga setelah Alquran dan Sunnah adalah ijma'. Ijma' menurut mazhab ini berarti kesepakatan dengan suara bulat dari ulama atas suatu persoalan. Kendati menjadi sumber hukum ketiga, mazhab Ja'fari tidak menganggap ijma' memiliki kekuatan hukum yang mandiri. Ijma' bukanlah huijah sejati yang mandiri. Ia dipandang sebagai huijah sepanjang ijma' tersebut men- jelaskan suatu hadis. Dengan demikian, ijma' hanyalah manifestasi dari hadis. Selain itu, ijma' yang dapat diterima hanyalah ijma' yang terjadi dalam periode Nabi atau periode para imam. Jika ada kesepakatan yang terjadi di kalangan ulama pada masa sekarang, maka tidak dapat dianggap sebagai ijma'. ${ }^{22}$

Sumber hukum keempat adalah akal. Akal dapat dianggap sebagai sumber hukum sejauh ia tidak bertentangan dengan apa yang diungkapkan oleh Alquran dan Sunnah. Kedudukannya hanya sebagai alat yang digunakan untuk menemukan hukum-hukum tertentu yang sebenarnya telah tersirat dalam al- Qur'an. Meskipun menerima akal sebagai sumber hukum, mazhab Ja'fari menolak menggunakan qiyass dan istihsan seperti halnya Abu Hanifah dalam mazhab Sunni. Mereka memandang qiyas dan istihsan hanya didasarkan atas khayal dan dugaan murni yang tidak sah dipakai sebagai dasar dalam menetapkan hukum. Menurut mereka, Alquran dan Sunnah sudah cukup menyuguhkan segala peraturan hukum yang diperlukan. ${ }^{23}$

21 Murtadha Muthahhari, Prinsip-prinsip Ijtihad antara Sunnah dan Shi'ah, terj. Fauzi Siregar dan Ahmad Rifa'i Hasan (Bandung: Pustaka Hidayah, 1995), h. 30;

22 Ayatullah Baqir ash-Shadr dan Murtadha Muthahhari, Pengantar Ushul Figh dan Ushul Figh Perbandingan, h. 146-147; Abdul Aziz Dahal, Ensiklopedi Hukum Islam, h. 798.

23 Ayatullah Baqir ash-Shadr dan Murtadha Muthahhari, Pengantar Ushul Figh, h. 147-148; Abdul Azis Dahal, Ensiklopedi Hukum Islam, h. 799; Murtadha Muthahhari, Imamah dan Kbilafah, terj. Satrio Pinandito (Jakarta: Firdaus, 1991), h. 53. 


\section{BEBERAPA PRODUK FIQH JA'FARI}

Produk-produk hukum fikih Ja'fari tidak banyak berbeda dengan ketentuan- ketentuan hukum fikih yang ada dalam mazhab fikih Sunni. Hanya terdapat beberapa ketentuan fikih Ja'fari yang secara mendasar tidak dikenal dan tidak berlaku dalam fikih Sunni. Di antaranya, adalah persoalan nikah mut'ah dan konsep khumus. Adapun mengenai persoalan-persoalan fikih lain tidak ditemukan perbedaan-perbedaan prinsipil, kecuali perbedaan-perbedaan kecil yang biasa terdapat dalam diskursus fikih.

\section{Nikah Mut'ah}

Nikah mut'ah adalah istilah lain dari kawin kontrak. Dalam nikah mut'ah ini, seseorang melakukan aqad nikah dengan menyebutkan lama waktu yang akan digunakan untuk melakukan perkawinan, semisal satu bulan, setengah tahun, satu tahun dan seterusnya. mazhab-mazhab fikih Sunni secara tegas melarang penyelenggaraan nikah model ini. mazhab Sunni meyakini, bahwa meskipun penyelenggaraan nikah ini pernah diperbolehkan oleh Nabi, namun telah dinasakh sehingga tidak lagi boleh dilakukan.

Sayyid Sabiq misalnya, mengemukakan beberapa alasan mengapa nikah jenis ini tidak lagi dibolehkan. Pertama, penyelenggaraan nikah mut'ah tidak sesuai dengan ketentuan-ketentuan hukum lain yang terkait seperti tersebut dalam Alquran, misalnya dengan ketentuan talaq, waris, dan iddah. Kedua, Naș-naș hadis secara tegas telah melarangnya, misalnya hadis yang diriwayatkan oleh Ibn Hibbān tentang sabda Rasulullah yang melarang penyelenggaraan nikah ini setelah mengijinkannya beberapa waktu sebelumnya. Hadis serupa diriwayatkan oleh al-Dāruquṭnī dari Abū Hurayrah. Ketiga, Umar ibn Khattab telah melarang nikah tersebut secara tegas di masa pemerintah- annya. Keempat, Ijma' ulama seluruhnya (kecuali Syi'ah) menyatakan haramnya nikah mut'ah. Kelima, Nikah mut'ah hanya bertujuan untuk penyaluran kebutuhan seksual. Tidak ada maksud-maksud lain yang ingin dicapainya, seperti maksud meneruskan keturunan, membina rumah tangga, dan mendidiik anak. Nikah yang hanya bertujuan untuk kepentingan biologis tidak lebih dari prostisusi yang dilegitimasi. ${ }^{24}$

Pelarangan nikah mut'ah oleh mazhab Sunni tersebut ditolak mentah-mentah oleh mazhab Ja'fari. Menurut mereka, semasa Rasulullah, masa Abu Bakar, dan paruh pertama pemerintahan Umar ibn Khattab, nikah jenis ini masih banyak dipraktikkan oleh beberapa sahabat yang dekat dengan Nabi. Antara lain adalah Zubayr ibn 'Awwām yang melakukan nikah mut'ah dengan Asma' binti Abū Bakr al-Shiddiq. Dari pernikahan tersebut lahir dua anak: Abdullāh ibn Zubayr (273 H/624-692 M) dan Urwah ibn Zubayr (w. 92 H/710 M). Dasar Alquran yang mereka gunakan adalah QS. al-Nisa' (4): 24 yang artinya: 'Maka isteri-isteri yang kamu telah campuri, berikanlah kepada mereka maharnya (dengan sempurna) sebagai suatu keewajiban.,25

Mazhab Ja'fari menyatakan bahwa pelarangan nikah mutah tersebut hanya terjadi pada masa Umar ibn Khattab. Umar melarang nikah mut'ah dan mengancam pelakunya dengan hukuman rajam. Sumber-sumber sejarah dalam mazhab Ja'fari, pada mulanya sebagian sahabat menentang larangan Umar tersebut, namun sebagian yang lain menerimanya. Pandangan mazhab Ja'fari, larangan Umar tersebut sifatnya hanya sementara untuk kepentingan politis. Sayangnya, menurut mereka, kemudian ada pelembagaan larangan tersebut, sehingga terkesan sebagai ketentuan syar'i yang orisinil. ${ }^{26}$

\section{Konsep Khumus}

Khumus menurut mazhab Ja'fari merupakan kewajiban mengeluarkan harta bagi kaum Muslimin, sebagaimana halnya zakat, yang diperuntukkan kepada abl al-bayt. Orang yang tidak menunaikannya termasuk dalam kelompok yang merampas hak-hak abl al-bayt. Khumus

${ }^{24}$ Sayyid Sābiq, Fiqh al-Sunnah, jilid II (Beirut: Dār al-Fikr, 1983/1403) h. 35-36

${ }^{25}$ Lihat Sayyid Muhammad Husain Fadlullah, Dumia Wanita dalam Islam, terj. Muhammad Abdul Qadir Alkaf (Jakarta: Lentera, 2000), h. 263-264; Abdul Azis Dahal, (ed.), Ensiklopedi Hukum Islam, h. 799.

26 Murtadha Muthahhari, Hak-hak Wanita dalam Islam, terj. M. Hashem (Jakarta: Lentera, 2001) h. 32-35; Sayyid Muhammad Hussein Fadlullah, Dunia Wanita dalam Islam, h. 264270; Abdul Azis Dahal, Ensiklopedi Hukum Islam, h. 799 
menurut mazhab Ja'fari sebenarnya telah diberlakukan pada masa Nabi, namun kemudian dihapuskan oleh Abu Bakar. Dasar yang digunakan oleh mazhab Ja'fari adalah QS. al-Anfal (8): 41 yang artinya: "Ketahuilah bahwa sesunggubnya apa saja yang kalian peroleh, maka seperlimanya (khumus) adalah untuk. Allah, Rasul, kaum kerabat, anak-anak yatim, orang-orang miskin, dan ibn sabil."27

Imam Mūsā al-Kaḍīm ibn Imām Ja'far al-Șādiq menafsirkan ayat di atas dengan mengatakan bahwa apa yang untuk Allah adalah untuk RasulNya, dan apa yang untuk Rasul-Nya adalah untuk abl al-Bayt-nya. Imam al-Ṣādiq juga pernah berkata:'Ketika Allah telah mengharamkan sedekah bagi kami, maka Allah menurunkan kbumus untuk kami. Sedekah adalah haram bagi kami, tetapi kbumus adalah hak kami" ${ }^{28}$

Harta yang wajib dikeluarkan kbumus-nya ada tujuh, yaitu: harta rampasan perang, barang tambang, harta terpendam (temuan), harta yang diambil dalam laut, harta penghasilan, tanah yang dibeli oleh kafir dimmī dari seorang Muslim, dan harta halal yang tercampur dengan yang haram. Meskipun ada tujuh harta yang wajib dikeluarkan kbumus-nya, namun yang disyaratkan memenuhi nishab hanya tiga harta, yakni harta yang diambil dalam laut (sebanyak satu dinar), barang tambang dan barang temuan (masing-masing sebanyak 20 dinar).

\section{KESIMPULAN}

Dari paparan di atas, kita bisa melihat ketokohan Imam Ja'far al-Ṣādiq, imam keenam dalam teologi Syi'ah, sebagai seorang ilmuwan dan ahli fikih yang kredibilitasnya diakui, tidak hanya di kelompok Syi'ah, namun juga di kelompok Sunni. Kredibilitas tersebut ditunjukkan oleh tidak sedikitnya beberapa ahli fikih Sunni yang pernah belajar kepadanya, juga dengan dikategorikannya Imam Ja'far dengan derajat thiqah dalam silsilah periwayatan hadis.

27 Muhammad Jawad Mughniyah, Fiqih Imam Ja'far Shadiq, h. 363; Abdul Azis Dahal, Ensiklopedi Hukum Islam, h. 799.

28 Muhammad Jawad Mughniyah, Fiqih Imam Ja'far Shadiq, h. 363.
Sumber-sumber hukum yang digunakan dalam mazhab Ja'fari tidak jauh berbeda dengan sumber-sumber hukum yang digunakan dalam mazhab Sunni, yakni berkisar seputar Alquran, Sunnah, Ijma', dan Akal. Meskipun terdapat pemahaman definisi yang berbeda mengenai sumber-sumber hukum tersebut, namun hal tersebut tidak menunjukkan bahwa Syi'ah dan Sunni memiliki perbedaan prinsip dalam penentuan hukum. Perbedaan penentuan sumber hukum semacam itu juga terdapat dalam diskursus ushul fikih empat mazhab fikih Sunni. Misalnya eksistensi qiyas yang diakui oleh Abu Hanifah, namun tidak mendapatkan tempat dalam mazhab Hambali. Karena itulah, dalam produk pemikiran fikih, hanya ditemukan beberapa perbedaan prinsipil, seperti misalnya dalam ketentuan mengenai nikah mut'ah dan kbumus. Sementara dalam ketentuan-ketentuan lain, hanya terdapat perbedaan- perbedaan kecil yang biasa terjadi dalam wacana fikih, seperti juga terjadi dalam tradisi fikihSunni. 


\section{DAFTAR KEPUSTAKAAN}

Abu Zahrah, Muhammad, Tarikh al-Madhahib al-Islamiyyah, jilid II, Beirut: Dar al-Fikr al-'Arabi, t.th.

al-'Asqalani, Shihab al-Din Abu al-Faḍl Aḥmad ibn 'Ali ibn Hajar, Tahdhib al- Tahdhib, jilid I, t.tp. : Dar alKitab al-Islami, t.th.

al-Andalusi, al-Imam Abu Muḥammad 'Ali ibn Aḥmad ibn Sa’id ibn Hazm,

Ashab al-Futya min al-Sahabah wa al-Tabiin wa Man Ba'dabum 'alaMaratibibim fi Kathrati al-Futya, Beirut: Dār al-Kutb al-'Ilmiyyah, 1415/1995.

Amīn, Aḥmad, Fajr al-Islām, t.tp: Dār al-Kutb, 1975.

Dahal, Abdul Azis, (ed.), Ensiklopedi Hukum Islam, jilid 3, Jakarta: Ichtiar Baru van Hoeve, 1996.

Fadlullah, Sayyid Muhammad Husain, Dunia Wanita dalam Islam, terj. Muhammad Abdul Qadir Alkaf, Jakarta: Lentera, 2000.

Glasse, Cyril, Ensiklopedi Islam (Ringkas), terj. Ghufron A. Mas'adi, ed. I, Jakarta: Raja Grafindo Persada, 1999.

Ḥakīm, 'Abd al-Ḥamid, al-Bayan, Jakarta: Maktabah al-Sa'diyyah, t.th.

Hughes, Thomas Patrick, Dictionary of Islam, New Delhi: Cosmo Publications, 1982.

Khallāf, 'Abd al-Wahhāb, Ilm al-Ușul Fiqh, Beirut: Dar al-Qalam, 1978/1398. Mughniyyah, Muhammad Jawwad, Fiqh Imam Ja'far Sadiq, terj. Samsuri Rifa’i, dkk., Jakarta: Lentera Basritama, 1999.

Muthahhari, Murtadha, Hak-bak W anita dalam Islam, terj. M. Hashem, Jakarta: Lentera, 2001.

Muthahhari, Murtadha, Imamah dan Khilafah, terj. Satrio Pinandito, Jakarta: Firdaus, 1991.

Rahman, Fazlur, Islam, terj. Ahsin Mohammad, Bandung: Pustaka, 1997. Sabiq, Sayyid, Fiqh al-Sunnah, jilid II, Beirut: Dār al-Fikr, 1983/1403.

Shaban, M.A., Sejarah Islam: (Penafsiran Baru) 600-750, terj. Machnun Husein, Jakarta: Raja Grafindo Persada, 1993.

al-Sharbini, 'Abdurraḥman, Hashiyah al-'Allamah al-Bannani 'ala Matn Jam' al- Jawami', juz II, Indonesia: Maktabah Dar Thya' al-Kutb al-'Arabiyyah, t.th.

Yatim, Badri, Sejarah Peradaban Islam, Jakarta: Raja Grafindo Persada, 2000. 